\title{
Indonesian medicinal plants as sources of secondary metabolites for pharmaceutical industry
}

\author{
Eti Nurwening Sholikhah \\ Department of Pharmacology and Therapy, Faculty of Medicine, Universitas Gadjah \\ Mada, Yogyakarta, Indonesia
}

DOI: http://dx.doi.org/10.19106/JMedSci004804201606

\begin{abstract}
Medicinal plants are widely used in traditional medicine in both underdeveloped and developing countries in the word until now. Some secondary metabolites isolated from medicinal plants have been developed as modern drugs. New antimalarial artemisinin is an example of modern medicine that developed from Artemisia annua L, a plant used in China since 4,000 years ago. Indonesia is endowed with a rich natural resource. The biodiversity comprises thousands plant species. Therefore, Indonesian flora and fauna are a remarkable opportunity for the development of secondary metabolites for pharmaceutical industry. The Indonesian National Agency for Drug and Food Control, Republic of Indonesia (Badan Pengawas Obat dan Makanan, Republik Indonesia = BPOM RI) classifies traditional medicine into three classes, namely jamu (Indonesian indigenous traditional medicine), standardized herbal medicine and phytopharmaca based on its scientific evidences. The BPOM also determined 9 medicinal plants for focusing research for drug development. This paper discusses some secondary metabolites and their pharmacological activities of the following 9 selected Indonesian medicinal plants namely Piper retrofractum Vahl, Andrographis paniculata Ness, Curcuma xanthorrhiza, Psidium guajava L, Syzigium polyanthi, Morinda citrifolia, Guazuma ulmifolia Lamk, Zingiber officinale, and Curcuma domestica collected from various publications. Furthermore, several modern drugs derived from medicinal plants are also discussed.
\end{abstract}

\section{ABSTRAK}

Tanaman obat telah digunakan secara luas dalam pengobatan tradisional baik di negaranegara belum dan sedang berkembang di dunia hingga saat ini. Beberapa metabolit sekunder dari tanaman obat telah dikembangkan menjadi obat modern. Antimalaria artemisinin adalah salah satu contoh obat moderen yang dikembangkan dari tanaman Artemisia annua $\mathrm{L}$, suatu tanaman obat yang digunakan di Cina sejak 4000 tahun yang lalu. Indonesia dianugerahi oleh kekayaan alam yang melimpah dengan ribuan keanekaragaman hayati yang terdiri dari ribuan spesies tanaman. Oleh karena itu flora dan fauna Indonesia sangat terbuka lebar untuk dikembangkan untuk kepentingan industri farmasi. Badan Pengawas Obat dan Makanan, Republik Indonesia (BPOM RI) mengelompokkan obat tradisional dalam tiga kelas yaitu jamu, obat herbal terstandar dan fitofarmaka berdasarkan bukti ilmiahnya. Ada 9 tanaman Indonesia yang telah ditetapkan oleh BPOM RI untuk menjadi fokus penelitian dan pengembangannya menjadi obat. Makalah ini mengulas tentang kandungan metabolit sekunder dan aktivitas farmakologi dari ke 9 tanaman obat tersebut dari berbagai publikasi yaitu cabe jawa (Piper retrofractum Vahl), sambiloto (Andrographis paniculata Ness), temulawak (Curcuma xanthorrhiza), jambu biji (Psidium guajava L),

$\overline{\text { Corresponding author: etinurweningsholikhah@ugm.ac.id }}$ 
salam (Syzigium polyantha), mengkudu (Morinda citrifolia), jati belanda (Guazuma ulmifolia Lamk), jahe (Zingiber officinale), dan kunyit (Curcuma domestica). Selain itu, beberapa obat modern yang telah berhasil dikembangkan dai tanaman obat juga dibahas.

Keywords: medicinal plants - pharmacological activities - pharmaceutical industry -secondary metabolite - traditional medicine

\section{INTRODUCTION}

Recently, medicinal plants are widely used in traditional health care in both developing and developed countries. Various traditional medicine (TM) from different cultures in the word used medicinal plants as the backbone for thier health care system. In Indonesia, the use of TM has been embedded on the national culture since centuries ago. As a mega biodiversity country, Indonesia is endowed with a rich natural resource including TM materials as a national asset that needs to be explored, researched, developed and optimized for their utilization. Therefore, the national asset has a value and comparative advantage as a major base in the capital utilization and development efforts to be competitive commodity. ${ }^{1}$

Some attempts have been conducted both at the global and regional level for the harmonization of standards and quality of TM. Therefore, the TM can be traded across countries with the same standards and quality. World Health Organization (WHO) has issued some policies concerning traditional medicine, such as WHO Traditional Medicine Strategy 2002-2005, ${ }^{2}$ National Policy on Traditional Medicine and Regulation of Herbal Medicine, ${ }^{3}$ and Development of Traditional Medicine in the South-East Asia Region. ${ }^{4}$ These policies have been adopted by WHO member countries including Indonesia in the development their TM potencies. As medicine, the use of TM must meet the requirements of safety and effectivenes. The
TM must be implemented based on scientific evidences to improve human health outcomes, including physical, mental and social wellbeing. Therefore UNESCO's International Bioethics Committee included the subject of TM in its work program for 2010-2011. ${ }^{5}$

Plant secondary metabolites play an important role in determining of biological activities of medicinal plants used in TM. Therefore, identification and isolation of the secondary metabolites are important to standardize and to increase quality of the TM. Over 24,000 stuctures of secondary metabolites have been isolated and evaluated its biological activities. Some of them have antinutritional and toxic effect on mammals. ${ }^{6}$ Moreover, some of plant secondary metabolites are successfully developed as modern drugs. At least 119 bioactive compounds from plant secondary metabolites that were being used as drugs. Some of these drugs are still obtained commercially, for the most part, by extraction from only about 90 species of medicinal plants. $^{7}$ With more than 250000 species of medicinal plants known to exist on this word, common sense dictates that many more useful drugs remain to be discovered from this medicinal plants.

Some examples of modern drugs developed from medicinal plants are new antimalarial artemisinin from Artemisia annua L, a plant used in China for many centuries, ${ }^{8}$ inotropic digitalis glycosides from Digitalis purpurea, ${ }^{9}$ anticancer of vinca alkaloids (vincristine and vinblastie, vindesine, and vinorelbine) from 
Catharanthus roseus ${ }^{10-12}$, antimuscarinic belladonna alkaloids (atropine, hyoscine or scopolamine) from Atropa belladonna, ${ }^{13}$ and antirheumatic colchicine commonly produced by plants like Colchicum autumnale and Gloriosa superb. ${ }^{14}$

Indonesia has the biodiversity comprises thousands plant species. Therefore, Indonesian flora is a remarkable opportunity for the development of secondary metabolites for pharmaceutical industry. The BPOM classifies the TM into three classes, namely traditional jamu, standardized herbal medicine jamu and phytopharmaca jamu based on its scientific evidences. Traditional jamu is Indonesian indigenous traditional medicine that its use just based on empirical experiences. Whereas, standardized herbal medicine jamu is dosage form of natural medicine which has been proven for its safety and pharmacological effect at preclinical study, and the material has been standardized and phytopharmaca jamu is dosage form of natural medicine which has proven for its safety and pharmacologycal effect preclinical and clinical study, and its material and product have been standardized. ${ }^{15}$

The BPOM also decided 9 plants to be research focus for drug development. These plants were investigated their biological activities by Indonesian and foreign researchers. Furthermore, the secondary metabolites of these plants were isolated and identified. However, their development both as TM or modern drugs remains stagnant. This paper discusses some secondary metabolites and their pharmacological activities of the 9 selected Indonesian medicinal plants that potentially developed as TM or modern drugs. Several modern drugs derived from medicinal plants are also discussed.

\section{DISCUSSION}

\section{Indonesian medicinal plants as source of secondary metabolites}

\section{Piper retrofractum Vahl (Cabe Jawa)}

Piper retrofractum Vahl (Piperaceae) is Indonesian indogenous plant. As a garden medicinal plant, it grows well in secondary forests lowland. The synonim of $P$. retrofractum Vahl is $P$. longum. This plant is known locally as cabe jawa, cabe jamu (in Java), cabe solak (Madura) and cabia (Sulawesi). Piper longum oils contain few secondary metabolites monoterpene hydrocarbons, a moderate content of sesquiterpenes and high content of aliphatic hydrocarbons. ${ }^{16}$ Piperidine alkaloids (FIGURE 1) from $P$. retrofractum Vahl. protect against high-fat diet-induced obesity. ${ }^{17}$

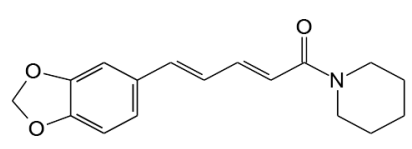

Piperine

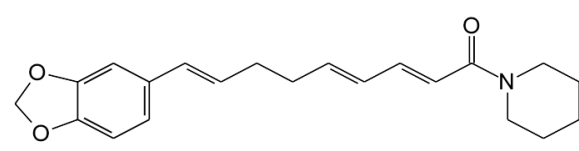

Dehydropipernonaline

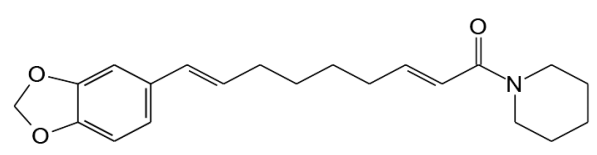

Pipernonaline

FIGURE 1. Piperidine alkaloids isolated from P. retrofractum Vahl 


\section{Andrographis paniculata Ness (Sambiloto)}

Andrographis paniculata Ness is very well known in Indonesia as a medicinal plant because of its bitter taste. It is known locally as sambiloto. Andrographis paniculata Ness is traditionally used to treat various diseases such as high blood pressure, fever, malaria, diabetes, gastrointestinal disorders, inflammation, dysentery and cancer. The main active compound is andrographolide (FIGURE 2). However it also contains flavonoids such as 5,7,2', 3'-tetrametoksiflavanon, 5-hydroxy-7, 2', 3'-trimetoksiflavon, ${ }^{18}$ 5-hydroxy-7', 2',6-trimetoksiflavon and 14-deoxy-15,1211 -isopropiliden-dehidroandrografolid. ${ }^{19}$ Andrographolide has been proven to have a variety of pharmacological activities such as anti-inflammatory, antibacterial, antidiabetic, and anticancer. Shi et al. ${ }^{19}$ reported that andrographolide inhibits invasion and migration of colorectal cancer cells by inhibiting the activity of MMP-7 expression, whereas Lee et $a l .{ }^{20}$ proved andrographolide inhibits invasion and migration of lung cancer cells (A-549) by inhibiting P13K/Akt signaling pathways. Some andrographolide derivatives have been successfully synthesized and tested for their anticancer activity by several researchers. Jada et $a{ }^{21}{ }^{21}$ reported that benzylidene derivatives of andrographolide inhibit growth of breast and colon cancer cells in vitro by inducing G(1) arrest and apoptosis.

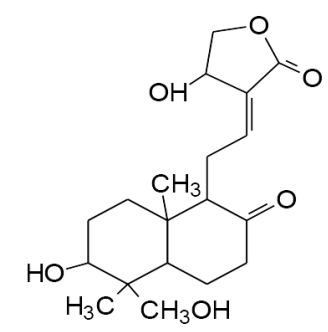

FIGURE 2. Andrographolide isolated from A. paniculata Ness

\section{Curcuma xanthorrhiza (Temu Lawak)}

Curcuma xanthorriza has been used traditionally by Indonesian people to cure acne, increased appetite, anti-cholesterol, antiinflammatory, anemia, antioxidant, cancer prevention, and antimicrobial. It is well known as temu lawak. Curcuma xanthorriza has a variety of pharmacological activities such as analgesic, antidiabetic, antihyperlipidemic and stimulants. Beside curcumin, some other specific active compound found in $C$. xanthorriza, i.e. xanthorrizol, ar-tumerone and $\alpha$-curcumin (FIGURE 3 ). Xanthorrizol as the main compound in C. xanthorriza has been proven as antioxidant and anti-inflammatory. ${ }^{22}$ Activity and cytotoxic mechanism of xanthorrizol in some cancer cells in vitro have been reported by several investigators. Ismail et al. ${ }^{23}$ reported xanthorrizol induce apoptosis of HeLa cells via the up-regulation of bax and p53. Xanthorrizol also showed antiproliferative activity in breast cancer cells MCF-7 via apoptosis induction through modulation of bcl-2, p53 protein and PARP1.24
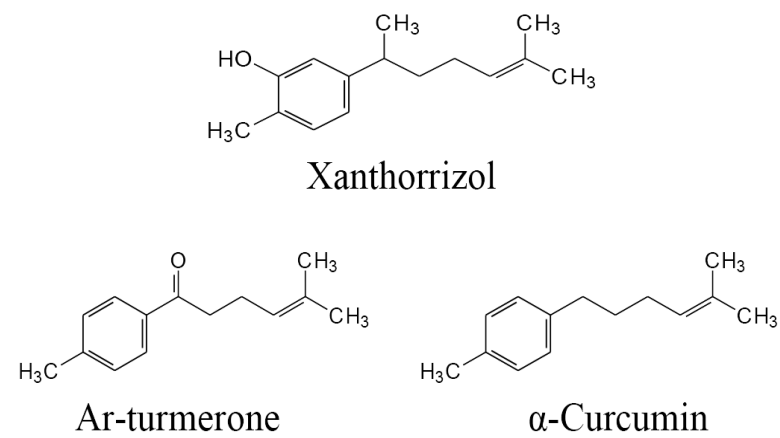

FIGURE 3. Some active compounds isolated from C. xanthorriza.

Another study conducted by Handayani et $a l^{25}$ proved that xanthorrizol has antiproliferative activity on hepatoma HepG2 cell by inducing apoptosis through p53, Bcl2 and caspase-dependent signaling pathway. Xanthorrizol also reported to inhibit the 
proliferation of HCT116 colon cancer cells line by inhibiting the cell cycle in the G0/G1 phase and $\mathrm{G} 2 / \mathrm{M}$ regulation through inhibition of cyclin A, B1, and D1 and cyclin-dependent kinase 1 (CDK1), CDK2 and CDK4. It also has p21, p27 and cyclin-dependent kinase inhibitors activity. ${ }^{26}$

\section{Psidium guajava L (Jambu Biji)}

Psidium guajava, commonly known as guava or jambu biji in Indonesia is belonging to family of Myrtaceae, native plant of tropical America and has long spread to southeast Asia. Guava is a fruit rich in bioactive compounds that may be used in various way to offer to the population the possibility of preventing certain chronic disease at low cost because of its antioxidant activity. ${ }^{27}$ Guava leaf extracts are rich sources of natural antioxidants and could be developed into functional food or drug against diseases and for a variety of beneficial chemo-preventive effects. ${ }^{28}$ Guava extract exerted a potent anti-nociceptive effect. ${ }^{29}$ Begum et al.$^{30}$ reported that two triterpenoids, 20 b-acetoxy-2a,3b-dihydroxyurs-12-en28-oic acid (guavanoic acid) and 2a,3bdihydroxy-24-p-z-coumaroyloxyurs-12-en28-oic acid (guavacoumaric acid) along with 2a-hydroxyursolic acid, jacoumaric acid, isoneriucoumaric acid, asiatic acid, ilelatifol $\mathrm{D}$, and b-sitosterol-3-O-b-d-glucopyranoside have been isolated from $P$. guajava leaves. The asiatic acid (FIGURE 4) showed spasmolytic activity. ${ }^{30}$<smiles>CC1CCC2(C(=O)O)CCC34CC35CCC3C(C)(CO)C(O)C(O)CC3(C)C4CC=C2C1C(C)C5C</smiles>

FIGURE 4. Asiatic acid isolated from P. guajava

\section{Syzigium polyanthi (Salam)}

Syzigium polyanthi with its synonym Eugenia polyantha or Indonesian bay leaf is one of spice used in Indonesia. It is known as salam in Java. It has antioxidant activity. ${ }^{31}$ Three phenolic pancreatic lipase inhibitors (FIGURE 5) were isolated from E. polyanthi. Although the activities of the isolated compounds were mild, the abundant content of hydroxychavicol in this spice makes it quite attractive as a food additive for the treatment and prevention of obesity. ${ }^{32}$<smiles>C=CCc1ccc(C)c(O)c1</smiles>

4-allyl-1,2-dihydroxybenzene

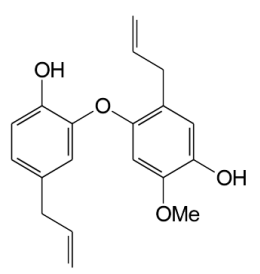

4-allyl-1-hydroxy-2-(2'-allyl-4' hydroxy-5'-methoxyphenoxy)benzene

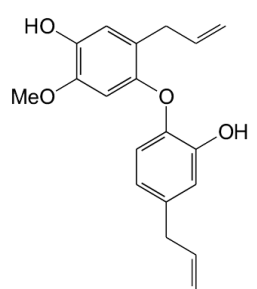

4-allyl-2-hydroxy-1-(2'-allyl-4'hydroxy-5'-methoxyphenoxy)benzene

FIGURE 5. Three phenolic pancreatic lipase inhibitors isolated from E. polyanthi. 


\section{Morinda citrifolia (Mengkudu)}

Morinda citrifolia has been used in traditional Polynesian medicine for over 2000 years. Its Indonesian name is mengkudu. It is reported to have a broad range of therapeutic effects, including antibacterial, antiviral, antifungal, antitumor, antihelmint, analgesic, hypotensive, anti-inflammatory, and immune enhancing effects. ${ }^{33}$ Morinda citrifolia is an evergreen shrub whose ripe fruit has a strong butyric acid smell and flavor. The leaves and especially the fruit are consumed in different forms by various communities throughout the world, the root is used as a dye. ${ }^{34}$ Morinda citrifolia aquous extract as well as its biomarker scopoletin (FIGURE 6) may be beneficial as a potential preventive and therapeutic agent for gastro-esophageal inflammatory diseases, mainly through its antisecretory and prokinetic activities including an inhibitory activity on serotonin, free radicals, and cytokinemediated inflammation. ${ }^{35,36}$ A known major component (scopoletin) in M. citrifolia was chosen as a marker and monitored in the plasma and in different organs over time by HPLC analysis. ${ }^{33}$ Other contents are alizarin, aucubin, aracetin, asperulocidic acid, citrifolinoside B, damnacanthal, 1,3-dihydroxy-6-methyl anthraquinone, 5,6-dihydroxylucidin, 2-methyl-4hydroxy-5,7-dimethoxyanthraquinone, 3-hydroxymorindone, 8-hydroxy-8-methoxy2-methyl-anthraquinone, lucidin, 2-methyl3,5,6-trihydroxyanthraquinone, morenone
1, morenone 2, morindanidrine, morindine, morindone, physcion, ruberythric acid, rubiadin, rubiadin monomethyl ether, soranjidiol, and ursolic acid. ${ }^{34}$<smiles>COc1cc2ccc(=O)oc2cc1O</smiles>

FIGURE 6. Scopoletin isolated from M. citrifolia

\section{Guazuma ulmifolia Lamk (Jati Belanda)}

In traditional medicine, the bark of G. ulmifolia Lamk, with local name jati belanda, is used in the treatment of diarrhea, hemorrhages, fever, inflammatory diseases, and as stimulant for uterine contractions. Dried leaves are brewed into tea in some countries and used for gastrointestinal diseases and dysentery. The aerial parts of $G$. ulmifolia Lamk have shown a gastroprotective effect against the injurious effect of NSAIDs (non-steroidal anti-inflammatory drugs) mainly by anti-inflammatory and radicalscavenging mechanisms. ${ }^{37}$ Fraction obtained from G. ulmifolia Lamk bark produces significant antihypertensive effects. The phenolic compounds such as oligomeric procyanidins were detected in the PCF by FAB+-MS and HPLC-DAD-ESI/ MS analysis. ${ }^{38}$ The chemical structure of polymeric proanthocyanidin and oligomeric proanthocyanidin were shown in FIGURE $7 .{ }^{39}$ 
<smiles></smiles>

Oligomeric proanthocyanidin

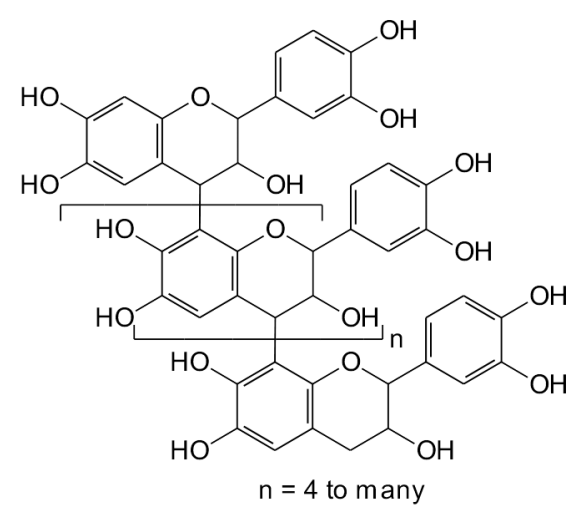

Polymeric proanthocyanidin

FIGURE 7. Oligomeric proanthocyanidin and polymeric proanthocyanidin isolated from G. ulmifolia

\section{Zingiber officinale (Jahe)}

Zingiber officinale or called jahe in Java, is known as seasoning. Traditionally, it also used as a carminative and stimulant, to increase appetite, treat the digestive tract disorder such as nausea and vomit, to treat common cold, cough, diarrhea, malaria, fever and arthritis. Some scientific research have proven that it has some pharmacological activity such as immunomodulator and antimicrobial, ${ }^{40}$ in vitro antihelminth, ${ }^{41}$ antinausea and vomiting, ${ }^{42}$ antioxidant, ${ }^{43}$ and anticancer. ${ }^{44}$<smiles>[R]c1ccc(CCC(=O)CC)cc1OC</smiles>

Paradol<smiles>COc1cc(CCCCC(=O)CCc2ccc(O)c(OC)c2)ccc1O</smiles>

1,7-bis-(40-Hydroxy-30methoxyphenyl)-4-heptene-3-one
Phytochemicalstudies of Z. officinale showed that it contains some chemical compounds from various groups such as paradol, dihydroparadol, gingerol, acetyl gingerol derivatives, shogaol, 3-dihydroshogaol, gingerdiol, mono-and diacetyl gingerdiol derivatives, 1-dehydrogingerdione, diarylheptanoide and metal ether derivatives. ${ }^{45}$ The chemical structure of some active compound of Z. officinale can be seen in FIGURE 8 . Among some active compounds, gingerol is compound which is often used by researchers as a marker for extract standardization.<smiles>COc1ccc(CCC(=O)CC(O)[18OH])cc1O</smiles>

Gingerol<smiles>COc1cc(CCC(=O)CC(=O)CCc2ccc(O)c(OC)c2)ccc1O</smiles>

1,7-bis-(40-Hydroxy-30-methoxyphenyl)3,5-heptadione

FIGURE 8. Some active isolated from Z. officinale. 


\section{Curcuma domestica (Kunyit)}

Curcuma domestica with its synonim $C$. longa is one of the ginger family, Zingiberaceae that widely distributed in Asia. ${ }^{46,47}$ Curcuma domestica has been used as seasoning, food coloring and traditional medicine. In Indonesia it is well known as jahe. As a traditional medicine, $C$. domestica has been used to treat various diseases such as diabetes, leprosy, gastrointestinal disorders, tonic, laxative, rheumatic, antiseptic, hepatic disorders, and cancer. Curcuma domestica contains curcumin and its derivatives such as bis-demetoxycurcumin, demetoxycurcumin. It contains active compounds such as curcumarol, $\alpha$-, $\beta$-and ar-turmerone, and zingiberene (FIGURE 9).

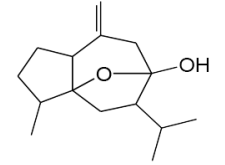

Curcumarol<smiles>O=C(CC=C1CCC(O)CC1)CC(O)C=Cc1ccc(O)cc1</smiles>

Bis-demetoxycurcumin<smiles>CC(C)=CCCC(C)C1C=CC(C)=CC1</smiles>

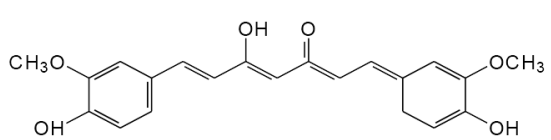

Curcumin<smiles>COC1CC(CCC(O)CC(=O)CCC2CCC(O)CC2)CCC1O</smiles>

Demetoxycurcumin<smiles>CC(C)=CC(=O)CC(C)c1ccc(C)cc1</smiles>

Ar-turmerone

FIGURE 9. Some active compounds of Curcuma domestica

Curcumin and its derivatives have been widely demonstrated to have great potential to be developed as anticancer. From several studies summarized by Aggrawal et al. ${ }^{48}$ showed that curcumin can inhibit the in vitro proliferation of various cancer cells such as $\mathrm{T}$ and $\mathrm{B}$ cell leukemia, colon cancer, skin cancer, breast cancer BT20, SKBR3, MCF7, T47D and ZR75-1. Various in vivo studies in experimental animal also showed that curcumin has chemopreventive and chemotherapeutic activities in animal models of cancer. Curcumin has been shown to inhibit tumor initiation induced by benzo(a) pirene and 7,12dimetilbenz (a) antrasen in mice. Curcumin is reported to suppress mouse skin tumor induced by forbol ester, suppress carcinogenesis in skin cancer, stomach, colon, liver and breast cancer in mice. ${ }^{49}$

\section{Modern drugs developed from medicinal plants}

\section{Artemisinin}

Artemisinin was isolated from Artemisia annua L, a plant used in China for many centuries. Artemisinin is a sesquiterpene lactone that bears a peroxide grouping and, unlike most other antimalarials, lacks 
a nitrogen-containing heterocyclic ring system. ${ }^{8}$ Subsequent studies of the structure activity relationship led to the discovery of dihydroartemisinin, artemether and artesunate. Artemisinin and these three derivatives (FIGURE 10) are being used around the world as effective new antimalarial drugs against falciparum malaria, including<smiles>CC1CCC2OC3(C)CCC1C(OC(=O)C2C)O3</smiles>

Artemisinin<smiles>COC1OC2OC3(C)CCC4C(C)CCC(C1C)C24O3</smiles>

Artemether multi-drug-resistant Plasmodium falciparum. At the present time new artemisinin analogues or derivatives are being developed. In addition, recent studies also indicate that some artemisinin derivatives have other biological activities including antiparasitic and anticancer activities. ${ }^{50}$<smiles>CC1CCC2C(C)C(O)OC3OC4(C)CCC1C32O4</smiles>

Dihydroartemisinin

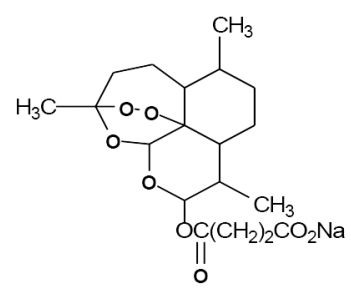

Artesunate

FIGURE 10. Artemisinin and its derivatives

\section{Digitalis glycosides}

Digoxin and digitoxin (FIGURE 11) known as cardiac glycosides is one example of a modern drug glycoside isolated from the plant digitalis (Digitalis purpurea)., ${ }^{9,51}$ Digoxin and digitoxin are cardiac glycoside with positive inotropic activity. They increase force and velocity of myocardial systolic contraction (positive inotropic action), slow heart rate, decrease conduction velocity through AV node, and decrease the degree of activation of the sympathetic nervous system and renin-angiotensin system. ${ }^{52}$

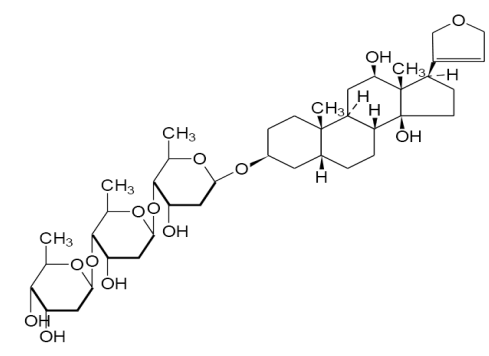

Digoxin

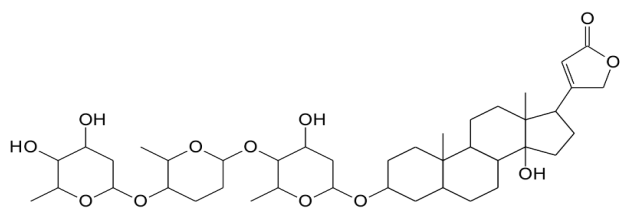

Digitoxin

FIGURE 11. Digoxin and digitoxin 


\section{Vincristine and vinbalastine}

Some anticancer used in cancer therapy firstly isolated from medicinal plants. Vinca alkaloids (vincristine and vinblastie) were isolated from Catharanthus roseus. ${ }^{10-12}$ Vinblastine and vincristine (FIGURE 12) are alkaloids which used for treatment of leukemias, lymphomas, and testicular cancer. A closely related derivative, vinorelbine, has important activity against lung cancer and breast cancer. ${ }^{52}$

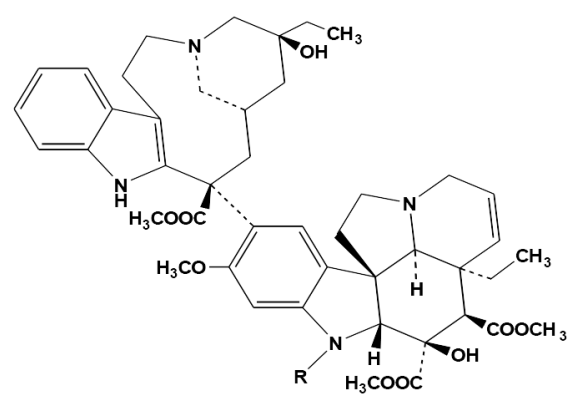

FIGURE 12. Vinblastine $(\mathrm{R}=\mathrm{CH} 3)$ and vincristine $(\mathrm{R}=\mathrm{CHO})$

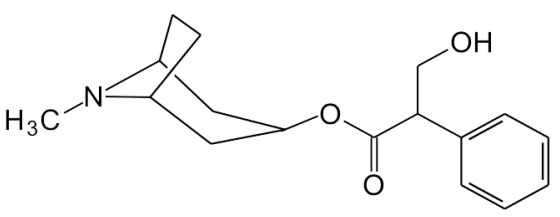

Atropine

\section{Atropine and hyoscine (scopolamine)}

Atropine is major alkaloids of Atropa belladonna. Further alkaloids in the leaves are apoatropine, tropine, scopolamine, aposcopolamine, 3- $\alpha$-phenyl-acetoxytropane, and tropinone. ${ }^{13}$ Atropine (FIGURE 13) inhibits action of acetylcholine or other cholinergic stimuli at postganglionic cholinergic receptors, including smooth muscles, secretory glands, and central nervous system (CNS) sites. Hyoscine (scopolamine) (FIGURE 13) competitively inhibits action of acetylcholine at muscarinic receptors. Principal effects are on iris and ciliary body (pupil dilations and blurred vision), secretory glands (dry mouth), drowsiness, euphoria, fatigue, decreased nausea, and vomiting. Atropine and scopolamine differ quantitatively in antimuscarinic actions, particularly in their ability to affect the CNS. Atropine has almost no detectable effect on the CNS at doses that are used clinically. In contrast, scopolamine has prominent central effects at low therapeutic doses. Because atropine has limited CNS effects, it is preferred to scopolamine for most purposes. $^{52}$

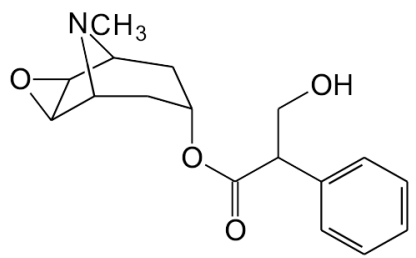

Hyoscine (scopolamine)

FIGURE 13. Atropine and hyoscine (scopolamine)

\section{Colchicine}

Colchicine is also known as methyl ether of colchicines. It is secondary metabolite commonly produced by plants like Colchicum autumnale and Gloriosa superba, It is originally used to treat rheumatic complaints, especially gout. ${ }^{14}$ Colchicine is one of the oldest available therapies for acute gout. It is considered second-line therapy due to a narrow therapeutic window and a high rate of side 
effects, particularly at higher doses. The exact mechanism of action of colchicine in gout is not completely known. However, it involves in a reduction of lactic acid production by leukocytes leads to a decrease in uric acid deposition, and a reduction in phagocytosis, with abatement of the inflammatory response. ${ }^{52}$

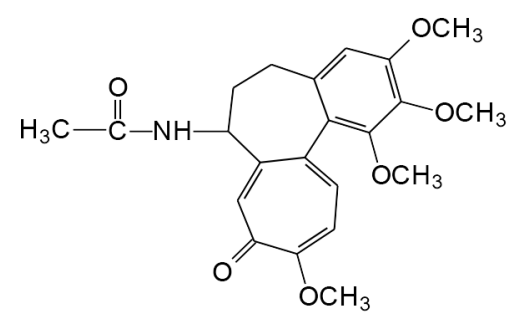

FIGURE 14. Colchicine

\section{CONCLUSION}

Many secondary metabolites have been isolated from Indonesian medicinal plants. Someofthemhavepotentialbiologicalactivities to further development for pharmaceutical industry both as TM or modern drugs. To develop the Indonesian medicinal plant as national product that can be competitive in multinational market, studies these plants for its safety, efficacy and standardization are necessary. Working collaboration between botanists, phytochemists, pharmacologists, organic chemists and others are important to pursue goal targeted.

\section{ACKNOWLEDGMENT}

Author would like to thank Prof. Dr. Mustofa from Department of Pharmacology and Therapy, Faculty of Medicine, Universitas Gadjah Mada for his suggestions and corrections during preparing of this manuscript.

\section{REFERENCES}

1. Departemen Kesehatan Republik Indonesia. Kebijakan obat tradisional nasional. Keputusan Menteri Kesehatan Republik Indonesia Nomor: 381/Menkes/SK/III/2007 Tanggal 27 Maret 2007. Jakarta: Departemen Kesehatan Republik Indonesia, 2007.

2. World Health Organization. WHO traditional medicine strategy 2002-2005. Geneva: World Health Organization, 2002.

3. World Health Organization. National policy on traditional medicine and tegulation of herbal medicine. Geneva: World Health Organization, 2005.

4. World Health Organization. Development of traditional medicine in the South-East Asia Region. New Delhi: World Health Organization Regional Office for South-East Asia, 2005.

5. UNESCO International Bioethics Committee, Report of the IBC on Traditional Medicine System and Their Ethical Implications, UNESCO International Bioethics Committee, SHS/EGC/IBC-19/12/3 Rev., Paris, 8 February 2013.

6. Makkar HPS, Siddhuraju P \& Becker K. Plant secondary metabolites. New Jersy: Humana Press, 2007. https://doi.org/10.1007/978-1-59745-425-4

7. FarnsworthNR. The role of ethnopharmacology in drug development. Ciba Found Symp 1990; 154: 2-11.

8. Klayman DL. Qinghaosu (artemisinin): an antimalarial drug from China. Science 1985; 228(4703): 1049-55. https://doi.org/10.1126/science.3887571

9. Bhowmik DC \& Kumar KPS. Traditional herbal drugs: digitalis and its health benefits. Int J Pharm Biomed Sci 2010; 1(1):16-9.

10. Ferguson PT, Phillips R, Seiner M, Cass CE. Differential activity of vincristine and vinblastine against cultured cells. Cancer Res 1984; 44:3307-12. 
11. Chu IH, Bodnar JA, Bowman RN \& White EL. Determination of vincristine and vinblastine in Catharanthus roseus plants byhigh performance liquid chromatography/ electrospray ionization mass spectrometry. J Liq Chromatogr Related Technol 1997; 20(8): 1159-74. https://doi.org/10.1080/10826079708010966

12. Rang HP, Dale MM, Ritter JM, Moore PK. Pharmacology. 5thed. London: Churchill Livingstone, 2003.

13. The European Agency for The Evaluation of Medicinal Products, Atropa Belladonna, Summary Report, Committee for Veterinary Medicinal Products, EMEA/MRL/540/98FINAL, Ade R, Rai MK. Review: colchicine. Curr Adv Future Prosp Biosci 2010; 2(2): 90-6.

14. Badan Pengawas Obat dan Makanan Republik Indonesia. Peraturan Kepala Badan Pengawas Obat dan Makanan Republik Indonesia Nomor: Hk.00.05.41.1384 Tentang kriteria dan tata laksana pendaftaran obat tradisional, obat herbal terstandar dan fitofarmaka. Jakarta: Badan Pengawas Obat dan Makanan Republik Indonesia, 2005.

15. Bhuiyan MNI, Begum J, Anwar MN. Volatile constituents of essential oils isolated from leaf and inflorescences of Piper longum Linn., The Chittagong Univ J B Sci 2008; 3(1 \&2): 7785.

16. Kim KJ, Lee M, Jo K, Hwang J. Piperidine alkaloids from Piper retrofractum Vahl. protect against high-fat diet-induced obesity by regulatinglipidmetabolismandactivatingAMPactivated protein kinase. Biochem Biophys Res Commun 2011; 411 (2011): 219-25. https://doi.org/10.1016/j.bbrc.2011.06.153

17. Koteswara RY, Vimalamma G, Rao CV, Tzeng YM. Flavonoids and andrographolides from Andrographis paniculata. Phytochemistry 2004; 65(16): 2317-21. https://doi.org/10.1016/j.phytochem. 2004.05.008
18. Reddy MK, Reddy MV, Gunasekar D, Murthy MM, Caux C, Bodo B. A flavone and an unusual 23-carbon terpenoid from Andrographis paniculate. Phytochemistry 2003; 62(8): 1271-75. https://doi.org/10.1016/S0031-9422 (03)00051-7

19. Shi MD, Lin HH, Chiang TA, Tsai LY, Tsai SM, Lee YC, et al. Andrographolide could inhibit human colorectal carcinoma Lovo cells migration and invasion via down-regulation of MMP-7 expression. Chem Biol Interact 2009; 180(3): 344-52. https://doi.org/10.1016/j.cbi.2009.04.011

20. LeeYC, Lin HH, Hsu CH, Wang CJ, Chiang TA, Chen JH. Inhibitory effects of andrographolide on migration and invasion in human nonsmall cell lung cancer A549 cells via downregulation of $\mathrm{PI} 3 \mathrm{~K} / \mathrm{Akt}$ signaling pathway. Eur J Pharmacol 2010; 632(1-3):23-32. https://doi.org/10.1016/j.ejphar.2010.01.009

21. Jada SR, Matthews C, Saad MS, Hamzah AS, Lajis NH, Stevens MF, et al. Benzylidene derivatives of andrographolide inhibit growth of breast and colon cancer cells in vitro by inducing $\mathrm{G}(1)$ arrest and apoptosis. $\mathrm{Br} \quad \mathrm{J}$ Pharmacol 2008; 155(5):641-54. https://doi.org/10.1038/bjp.2008.368

22. Lim CS, Jin DQ, Mok H, Oh SJ, Lee, JU, Hwang JK, et al. Antioxidant and antiinflammatory activities of xanthorrhizol in hippocampal neurons and primary cultured microglia. J Neurosci Res 2005; 82(6): 831-88. https://doi.org/10.1002/jnr.20692

23. Ismail $\mathrm{N}$, Pihie $\mathrm{AH}$, Nallapan M. Xanthorrhizol induces apoptosis via the up-regulation of Bax and p53 in Hela cells. Anticancer Res 2005; 25(3B): 2221-7.

24. Cheah YH, Azimahtol HL, Abdulla NR. Xanthorrhizol exhibits antiproliferative activity on MCF-7 breast cancer cells via apoptosis induction. Anticancer Res 2006; 26(6B): 4527-34. 
25. Handayani T, Sakinah S, Nallappan M, Pihie AH. Regulation of p53-, Bcl-2- and caspasedependent signaling pathway in xanthorrhizolinduced apoptosis of Hepg2 hepatoma cells. Anticancer Res 2007; 27(2): 965-71.

26. Kang YJ, Park KK, Chung WY, Hwang JK, Lee SK. Xanthorrhizol, a natural sesquiterpenoid, induces apoptosis and growth arrest in HCT116 human colon cancer cells. J Pharmacol Sci 2009; 111(3): 1276-84. https://doi.org/10.1254/jphs.09141FP

27. Chiari BG, Severi JA, Pauli-Credendio PA, Sylos CM, Vilegas M, Correa MA, et al. Assessment of the chemical profile of polyphenol content and antioxidant activity in extracts of Psidium guajava L. fruits. Int $\mathrm{J}$

28. Venkatachalam $\mathrm{RN}$, Singh $\mathrm{K}$, Marar $\mathrm{T}$. Phytochemical screening and in vitro antioxidant activity of Psidium guajava, Free Rad Antiox 2012; 2(1).

29. Somchit MN, Ahmad SZ, Israf DA, Hosni H. Non-opioid anti-nociceptive effect of Psidium guajava leaves extract. J Nat Remedies 2004; 4(2): 174-8.

30. Begum S, Hassan SI, Siddiqui BS, Shaheen F, Ghayur MN, Gilani AH. Triterpenoids from the leaves of Psidium guajava. Phytochemistry 2002; 61: 399-403. https://doi.org/10.1016/S0031-9422(02) 00190-5

31. Wong SP, Leong LP, Koh JHW. Antioxidant activities of aqueous extracts of selected plants. Food Chem 2006; 99: 775-83. ht tps://doi.org/10.1016/j. foodchem.2005.07.058

32. Kato E, Nakagomi R, Gunawan-Puteri MDPT, Kawabata J. Identification of hydroxychavicol and its dimers, the lipase inhibitors contained in the Indonesian spice, Eugenia polyanthi. Food Chem 2013; 136: 1239-42. ht tps://doi.org/10.1016/j . foodchem.2012.09.013
33. Wang MY, West BJ, Jensen CJ, Nowicky D, Su C, Palu AK, Anderson G. Morinda citrifolia (Noni): a literature review and recent advances in noni research. Acta Pharmacol Sin 2001; 23 (12): $1127-41$.

34. Chan-Blanco Y, Vaillant F, Perez AM, Reynes M, Brillouet J, Brat P. The noni fruit (Morinda citrifolia L.): a review of agricultural research, nutritional and therapeutic properties. $\mathrm{J}$ Food Composit Anal 2006; 19:645-54. https://doi.org/10.1016/j.jfca.2005.10.001

35. Mahattanadul S, Ridtitid W, Nima S, Phdoongsombut N, Ratanasuwon P, Kasiwong S. Effects of Morinda citrifolia aqueous fruit extract and its biomarker scopoletin on reflux esophagitis and gastric ulcer in rats. J Ethnopharmacol 2011; 134: 243-50. https://doi.org/10.1016/j.jep.2010.12.004

36. Nima S, Kasiwong S, Ridtitid W, Thaenmanee N, Mahattanadul S. Gastrokinetic activity of Morinda citrifolia aqueous fruit extract and its possible mechanism of action in human and rat models. J Ethnopharmacol 2012; 142: 354-61. https://doi.org/10.1016/j.jep.2012.04.044

37. Berenguer B, Trabedala C, Sanchez-Fida S, Quilez A, Mino P, De la Puerta R, et al. The aerial parts of Guazuma ulmifolia Lam. protect against NSAID-induced gastric lesions. J Ethnopharmacol 2007; 114(2):153-60, 2007

38. Magos GA, Mateos JC, Paez E, Fernandez G, Lobato C, Marquez C, et al. Hypotensive and vasorelaxant effects of the procyanidin fraction from Guazuma ulmifolia bark in normotensive and hypertensive rats. J Ethnopharmacol 2008; 117: 58-68. https://doi.org/10.1016/j.jep.2008.01.015

39. Hor $M$, Heinrich $M$, Rimpler $H$. Proanthocyanidin polymers with antisecretory activity and proanthocyanidin oligomers from Guazuma ulmifolia Bark. Phytochemistry 1996: 42(1): 109-19. https://doi.org/10.1016/0031-9422 (95)00855-1 
40. Tan BKH \& Vanitha J. Immunomodulatory and antimicrobial effects of some traditional chinese medicinal herbs: a review. Curr Med Chem 2004; 11: 1423-30. https://doi.org/10.2174/0929867043365161

41. Iqbal Z, Nadeem QK, Khan MN, Akhtar MS, Waraich FN. In vitro anthelmintic activity of Allium sativum, Zingiber officinale, Curcurbita mexicana and Ficus religiosa. Int J Agri Biol 2001; 3(4): 454-57.

42. Ernst E \& Pittler MH. Efficacy of ginger for nausea and vomiting: a systematic review of randomized clinical trials. $\mathrm{Br} \quad \mathrm{J}$ Anaesth 2000; 84(3):367-71. https://doi.org/10.1093/oxfordjournals.bja. a013442

43. Ghasemzadeh A, Jaafar HZ, Rahmat A. Antioxidant activities, total phenolics and flavonoids content in two varieties of Malaysia young ginger (Zingiber officinale Roscoe). Molecules 2010; 15(6): 4324-33. https://doi.org/10.3390/molecules15064324

44. Kandu JK, Na HK, Surh YJ. Gingerderived phenolic substances with cancer preventive and therapeutic potential. Forum Nutr 2009; 61:182-92. https://doi.org/10.1159/000212750

45. Jolad SD, Lantz RC, Solvon AM, Chen GJ, Bates RB, Timmermann BN. Fresh organically grown ginger (Zingiber officinale): composition and effects on LPS-induced PGE2 production. Phytochemistry 2004; 65:1937-54. h t tps://doi.org/10.1016/j . phytochem.2004.06.008
46. World Health Organization. WHO Monograph on selected medicinal plants, Volume 1. Geneva: World Health Organization, 1999.

47. Itokawa H, Shi Q, Akiyama T, MorrisNarschke SL, Lee KH. Recent advances in the investigation of curcuminoids. Chinese Med 2000; 3(11): DOI: 10.1186/1749-8546-3-11 https://doi.org/10.1186/1749-8546-3-11

48. Aggarwal BB, Kumar A, Bharti AC. Anticancer potential of curcumin: preclinical and clinical studies. Anticancer Res 2003; 23 (1A): 363 98.

49. Aggarwal BB, Kumar A, Aggarwal MS, Shishodia S. Curcumin derived from turmeric (Curcuma longa): a spice for all Seasons. In: Debasis, B. \& Garrys, G.P (Eds), Phytopharmaceutical in cancer chemoprevention. London: CRC Press, LLC, 2005: 350-87.

50. Li Y \& Wu Y L. How chinese scientists discovered Qinghaosu (artemisinin) and developed its derivatives? What are the future perspectives?. Med Trop 1998; 58 (Suppl. 3): 9-12.

51. Sharma K \& Purkait B. Identification of medicinally active ingredient in ultradiluted digitalis purpurea : fluorescence spectroscopic and cyclic-voltammetric study. J Anal Methods Chem 2012; DOI: 10.1155/2012/109058 https://doi.org/10.1155/2012/109058

52. Brunton LL, Parker KL, Blumenthal DK, Buxton ILO, (Eds) Goodman \& Gilman's manual of pharmacology and therapeutics. New York: The McGraw-Hill Companies, Inc., 2008. 